\title{
DOCUMENTO
}

\section{MÉTODO INTUITIVO E LIÇÕES DE COISAS POR FERDINAND BUISSON}

\author{
Maria Helena Camara Bastos \\ Pontifícia Universidade Católica do Rio Grande do Sul, Brasil.
}

\section{$\cos 80$}

erdinand Buisson (1841-1931) é um dos intelectuais e educadores franceses que significativa influência teve nos escritos e nas atividades de figuras da elite intelectual brasileira, especialmente de Rui Barbosa e Menezes Vieira ${ }^{2}$. No Brasil, a

\footnotetext{
${ }^{1}$ Ferdinand Buisson nasceu em dezembro de 1841, de uma família protestante de pequenos magistrados. A saúde o impediu de entrar na École Normale Supériere. Recusou-se a prestar juramento ao Império e, em conseqüência, renunciou a todos os postos universitários na França, apesar de seu sucesso no concurso para professor universitário de filosofia em 1868. Depois de 1866, ensinou filosofia e literatura comparada na Academia de Neuchâtel. Também passou a escrever alguns textos, nos quais expos sua concepção de uma Igreja liberal. Defendeu a liberdade de pensamento, o ensino popular, o ideal pacifista. Fez parte do Primeiro Congresso Internacional da Paz e da Liberdade, presidido por Garibaldi, em 1868, em Genebra. O segundo congresso ocorreu em Lausane, em 1869, sob a presidência de Vitor Hugo. Nessa ocasião, Buisson discursou pela supressão das armas, no que foi muito reprovado. Depois de 4 de setembro de 1870, retornou à Paris. Jules Simon Ihe nomeia, em 1871, para um posto de inspetor primário da região do Sena. Esta nomeação provocou a intervenção indignada do monsenhor Dupanloup. Jules Simon anula a nomeação, mas reserva à Buisson outros serviços, nomeando-o secretário da Comissão da Estatística do Ensino Primário. Com este cargo, representou a França na Exposição de Viena (1873), depois na de Filadélfia (1876). Empreendeu a publicação do Dictionnaire de pédagogie. Jules Ferry nomeia-o inspetor geral, depois diretor do Ensino Primário (1879). Buisson é seu colaborador mais importante e participou da preparação e do estudo de todas as reformas escolares. Em 1896 ocupou a cadeira de Pedagogia na Sorbonne. Defensor ardoroso de Dreyfus, foi um dos fundadores da Liga de Direitos do Homem. Em 1902 assumiu uma cadeira no legislativo como deputado, eleito pelos radicais e pelos socialistas do $13^{\circ}$ bairro de Paris. Foi o relator da lei sobre ensino de ordens religiosas, presidiu a comissão da separação da Igreja e do Estado, interveio constantemente à favor dos professores primários. Em 1914 foi presidente da Liga dos Direitos do Homem, da Liga do Ensino, da Sociedade pela Instrução Elementar, da Sociedade de Sociologia. A partir de 1927 abandonou a vida pública. Nesse mesmo ano recebeu o Prêmio Nobel da Paz, que o dividiu com a pacifista alemã Quidde (Ozouf, 1982, p. 239-241).

${ }^{2}$ Sobre a apropriação das idéias de Buisson no Brasil ver Bastos (2002).
} 
força e o prestígio de suas idéias residem, em grande parte, na posição política e profissional que ocupou ${ }^{3}$. Ou seja, o fato de ser inspetor geral da Instrução Pública na França (1878), diretor do Ensino Primário (1879), redator da Revue Pédagogique, professor da Sorbonne (1887), Ihe dá o prestígio para que outros o citem, reforçando as idéias de modernidade sobre educação escolar.

Foi um intelectual dos mais importantes do século 19, que teve um papel significativo na elaboração das leis Jules Ferry e da lei de separação das Igrejas do Estado. Liberal, republicano e pacifista, acreditava que a guerra seria abolida pela via da instrução, da educação popular e de uma ação laica. Para ele, a função da escola na sociedade moderna seria de fazer os homens "inteligências esclarecidas e consciência de direitos" (Buisson, 2003, p. 90).

Entre seus escritos, os mais citados e utilizados são o Rapport sur l'instruction primaire à l'Exposition Universelle de Vienne en $1873^{4}$, o Rapport sur l'instruction primaire à l'Exposition Universelle de Philadelphie en $1876^{5}$ e a Conférence sur l'enseignement intuitif, faite aux Instituteurs délégués à L'Exposition Universelle en 1878.

Além desses, destaca-se a direção do Dictionnaire de Pédagogie et d'Instruction Primaire (1878- 1887), considerado "A Bíblia da escola republicana, [...] um thesaurus monumental, em língua francesa, do ensino primário e de sua pedagogia" (Dubois, 2001, 59). Foi concebido em 1876 e devia, inicialmente, aparecer em 1878, por ocasião da Exposição Universal de Paris, em um único volume de mil páginas. Na realidade, nove anos, de 1878 à 1887, e 360 autores foram necessários para concluir sua publicação em quatro volumes e 5.600 páginas $^{6}$. A primeira parte, que compreende dois volumes, é denominada geral ou teórica. A segunda parte é considerada uma "verdadeira

\footnotetext{
${ }^{3}$ Martine Brunet (2000, p. 1) assim descreve a atuação de Ferdinand Buisson: "protestant libéral, directeur de l'enseignement primaire pendant 17 ans (1879-1896), fut le "génie de la laïcitée", fondateur du dictionnaire de pédagogie, créateur de la chaire des sciences de l'éducation à la Sorbonne, dreyfusard, député radical-socialiste, ardent militante du pacifisme (il obtint le prix Nobel de la paix)".

${ }^{4}$ Este relatório tem a seguinte organização: Organisation de l'exposition scolaire à Vienne; La maison d'école; Mobilier scolaire; Salles d'asile et jardins d'enfants; Méthode intuitive; De l'organisation pédagogique; L'instruction morale et religieuse; Lecture, écriture et langue maternelle; Histoire et géographie; Arithmétique et sciences usuelles; Enseignement agricole; Enseignement du dessin; Enseignement primaire complémentaire, cours d'adultes, bibliothèques populaires; Écoles normales; Resultats généraux et statistique de l'enseignement primaire.

${ }^{5}$ Este relatório tem a seguinte organização e autores: 1. Le Free school system (l'éducation nationale aux États-Unis) - Buisson; 2. Organisation administrative (autorités scolaires, personnel, classification des établissements) - Laporte; 3. Organisations financiére (budget de l'instruction publique) - Laporte; 4. Organisation pédagogique (écoles urbaines) - Laporte; 5 . Organisation pédagogique (écoles rurales) Laporte; 6. La coéducacion des sexes - Buisson); 7. L'instruction primaire dans les États du Sud - Buisson; 8. Maisons d'école et mobilier - Berger; 9. Education du premier âge (infant schools, jardin d'enfants, primary schools) - Berger; 10. Lecture - Valens; 11 Écriture - Valens; 12. Enseignement de la langue maternelle - Berger; 13. Géographie - Buisson; 14. Histoire et instruction civique - Buisson; 15. Arithmétique - Olagnier; 16. Tenue des livres, algèbre, géométrie et dessin géométrique - Olagnier; 17. Sciences phisiques et naturelles - Valens; 18. Enseignement du dessin (histoire des méthodes) - Berger; 19. Exposition du dessin dans les écoles primaires - Rauber; 20. Chant et musique - Valens; 21. Gymnastique - Rauber; 22. Instruction religieuse - Buisson; 23. Éducation morale - Buisson; 24. Enseignement primaire supérieur - Buisson; 25. Écoles normales - Berger; 26. Cours Pédagogiques et Examens de capacité - Berger; 27. Institutions Auxiliaires - Berger; 28. L'enseignement libre (écoles privées) - Rauber; 29. Statistique scolaire - Buisson et Laporte; 30. Resumé et Conclusions - Buisson.

6 Verbetes escritos por Buisson: Abstração, atividade, analogia, camaradas, caráter, Condorcet, conversação, crítica, curiosidade, disciplina, escola, educação, emulação, infância, Mulher, Ferry, História Santa, Instituteur, Instituttrice, instrução pública, intuição e método intuitivo, laicidade, liberdade do ensino, leis escolares, moral, neutralidade (neutralidade escolar), obrigação, pai, política, rezar, religião.
} 
enciclopédia prática de conhecimentos necessários ou úteis ao professor primário e ao professor da escola normal" (Dubois, 2001, p. 62). Em 1911, outra edição é realizada e intitulada Nouveau dictionnaire de pédagogie et d'instruction primaire, com acréscimos de verbetes e novos autores. Por sua monumentalidade, Pierre Nora (1984) o considera a "catedral da escola primária". Como tal, traz inúmeros verbetes que fazem um balanço e análise do sistema educacional e das práticas pedagógicas dos países mais desenvolvidos. Expressam inovações do sistema educacional e escolar, como modelo a ser adotado em um projeto republicano e de modernização da sociedade.

A tradução da Conférence sur l'enseignement intuitif, faite aux instituteurs délégués à L'Exposition Universelle en 1878 visa a contribuir para os estudos sobre o método intuitivo e lições de coisas ${ }^{7}$, que juntamente com o Relatório da Exposição Universal de Filadélfia de 1876 são os documentos que possibilitam sua apropriação e adoção pelos educadores brasileiros.

Para Buisson, o método intuitivo seria a doutrina pedagógica da escola laica ${ }^{8}$ e, portanto, faz parte da história das concepções educativas e das práticas escolares que dominaram, e porque não dizer que ainda fazem parte do cotidiano escolar ${ }^{9}$, como método de aplicação aos conhecimentos de ordem sensível e como método de uma escola ativa.

Nessa conferência, aborda a compreensão do método intuitivo nas três dimensões: intuição sensível, intuição intelectual, intuição moral. Parte da história do método, remetendo a Pestalozzi, ao ensino pelo aspecto de Froebel, e mesmo, para Emílio, de Jean-Jacques Rousseau, e à Didática magna de Comenius. Traz a diferença de abordagem entre a Alemanha e a França, destacando a contribuição de Marie PapeCarpantier $^{10}$, que adapta o método intuitivo e as lições de coisas como procedimento pedagógico à primeira infância e não somente à aprendizagem da observação própria a uma iniciação de uma educação científica (Kahn, 2002, p. 15). Para Charles Delon (1887), foi Marie Pape-Carpantier que teve o mérito de introduzir e popularizar a lição de coisas como um instrumento de instrução e de educação:

\footnotetext{
${ }^{7}$ Ver Schelbauer (2003; 2005); Valdemarin (2000; 2004); Teive (2008).

${ }^{8}$ Sobre o verbete Laicidade de F. Buisson, ver Bastos (2010).

9 Basta folhear a revista Nova Escola (Abril Cultural) para constatar a inserção de quadros murais para estudo de diferentes temas e conteúdos do currículo escolar, ainda hoje. Recentemente, na França, o periódico L'Air du temps (Paris, mardi 2 nov. 2010, p. 29) publicou a reportagem intitulada Pedagogie de l'image, em que informa que os quadros murais fazem seu retorno na escola e aborda, especialmente, as gravuras da Maison Deyrolle. Também podemos citar os suplementos murais editados nas décadas de 1950 a 1970 pela Revista do Ensino/RS (Bastos, Lemos, Busnello, 2005).

${ }^{10}$ Marie Pape-Carpantier tem uma significativa importância para a educação da criança de 2 a 6 anos. Sua influência situa-se na adoção do método intuitivo para a educação dos sentidos - lições de coisas -, na proposta pedagógica destinada à educação infantil - salas de asilo; no ensino de primeiras letras; na criação de materiais didáticos para auxiliar no desenvolvimento do método natural; na orientação de modelos de mobílias para as escolas. Produziu uma imensa obra para professores e alunos, traduzida em vários países - Grécia, Inglaterra, Itália, Suécia, Espanha, Brasil -, e publicada até a segunda década do século 20. O estudo analisa a trajetória e contribuição da educadora, destacando as principais idéias, pelo espírito prático e experimental, que prenunciam a escola ativa. Em 1868 também publicou Conferénces pédagogiques faites aux instituteurs reunis à la Sorbonne, tendo por objeto a aplicação do método das salas de asilo, das lições de coisas ou do método natural nas escolas primárias. Nestas conferências, estabeleceu a teoria das lições de coisas, universalizando seu uso em todas as disciplinas, que devia seguir a ordem em que se sucedem as percepções da inteligência: inicialmente, despertar a curiosidade da criança, a partir da identificação da cor, forma, uso, matéria, origem dos objetos, para depois iniciar as lições de coisa propriamente ditas. Ver Bastos (2010).
} 
Só a lição de coisas coloca o aluno na presença dos fatos materiais, com realidades visíveis e tangíveis, não mais de abstrações. A lição intuitiva dá às coisas e palavras, às palavras com as coisas - observação dos fatos e comunicação da linguagem. Mas é do ponto de vista educativo que a lição de coisas tem mais valor. Ela tem essencialmente por objetivo desenvolver e exercitar os orgãos, a inteligência, o julgamento; de suscitar o espírito de observação e pesquisa, a iniciativa pessoal; comparar com outros objetos, generalizar suas observações, raciocinar e concluir. Apela para todas as faculdades e operações de sua inteligência. Convida a pensar e a exprimir seu pensamento, a imaginar. Desenvolve o ser física e intelectualmente, os sentidos e a alma, o senso prático e o senso moral e estético. Serve para o ensino coletivo e essencialmente oral. (Delon, 1887, p. 5)

Buisson também assinala a necessidade da história natural aceder à dignidade de ensino elementar fundamental. Somente em 28 de março de1882, com a lei da obrigação escolar, com a escola laica, novas disciplinas foram incluídas no programa da escola primária, além do ler, escrever e contar: poesia, literatura, história e geografia, desenho, música coral, ginástica, noções de história natural, excursões escolares, trabalho manual, as quais formam a "virtude educativa de uma educação liberal".

O autor ainda destaca que lição de coisas é um procedimento de ensino, uma das aplicações do método intuitivo, não é uma disciplina, mas deve estar presente em todas as atividades de ensino em todo o período escolar, pois envolve tudo que se refere à vida e a todos os fenômenos da natureza. Isto é, apresentado como início e o fim de todos os estudos experimentais, como lições de observação, de informação, de palavras.

O ensino pelos sentidos e a educação para a aprendizagem dos sentidos marca de forma significativa a primazia da observação sobre a experimentação nas práticas escolares. O método intuitivo, o ensino pelos sentidos, especialmente a visão (enseignement pour les yeux) e a lição de coisas estimulam uma produção variada de recursos didáticos ${ }^{11}$.

Para Halbwachs (1925, p. 281),

não há idéias sem imagens: mais precisamente, idéia e imagem não designam dois elementos - um social e outro individual - de nossos estados de consciência, mas dois pontos de vista de onde a sociedade pode examinar os objetos, ao mesmo tempo em que os situa no conjunto de suas noções, ou em sua vida e sua história. (apud Jodelet, 2001, p. 39)

\section{Referências}

BARBOSA, Rui. Reforma do ensino primário e várias instituições complementares da instrução pública - 1883. In: Obras completas de Rui Barbosa, v. 10, tomo I, II, III, IV. Rio de Janeiro: Ministério da Educação e Saúde, 1947.

\footnotetext{
${ }^{11}$ Feldman (2004, p. 94), destaca a função educativa das imagens na sala de aula: representam o mundo segundo padrões relacionados com a moralidade, a praticidade e a pátria; representam a realidade de forma estereotipada e idealizada, ordenando-o e simplificando-o; impõem uma ordem coincidente com o padrão do currículo. Sobre a pedagogia e a imagem ver Renonciat; Simon-Oikawa (2009).
} 
BASTOS, Maria Helena Camara. Ferdinand Buisson no Brasil: pistas, vestígios e sinais de suas idéias pedagógicas (1870-1900). História da Educação. Pelotas: Asphe, v. 4, n. 8, 2000, p. 79-109.

BASTOS, Maria Helena Camara; LEMOS, Elizandra Ambrósio; BUSNELLO, Fernanda Bastani. Pedagogia da ilustração: uma face do impresso. In: BENCOSTTA, Marcus Levy Albino (org.). Culturas escolares, saberes e práticas educativas: itinerários históricos. São Paulo: Cortez, 2007, p. 41-78.

BASTOS, Maria Helena Camara. Educação infantil e ensino intuitivo: a contribuição de Marie Pape-Carpantier (1815-1878). Revista Conjectura, v. 17, n. 3, 2010, p. 2-33.

BASTOS, Maria Helena Camara. Introdução Verbete Laicidade. BUISSON, Ferdinand. Verbete Laicité/Laicidade. Dictionnaire de pédagogie et d'instruction primaire publié sous la direction de Ferdinand Buisson (1878-1887, p. 1469-1474). História da Educação. Pelotas: Asphe, v. 14, n. 32, 2010, p. 267-276.

BROGLIE, Louis Albert de Deyrole. Leçons de choses. Paris: Michel Lafon, 2010.

BUISSON, Ferdinand. Éducation et republique. Paris: Kimé, 2003, p. 78-83.

BRUNET, Martine. Ferdinand Buisson éducateur et pacifiste. Paris: Paris Sorbonne IV, 2000.

BUISSON, Ferdinand. Conférence sur l'enseignement intuitif : conférences pédagogiques faites aux Instituteurs délégués à L'Exposition Universelle de 1878. 31 août 1878. Paris: Ch. Delagrave, 1897.

BUISSON, Ferdinand. Conférence et causeries pédagogique. Paris, CH.Delagrave et Hachette, 1888.

BUISSON, Ferdinand. Dictionnaire de pédagogie et d'instruction primaire (extraits). Établissement du texte, présentation et notes par Pierre Hayat. Paris: Kimé, 2000.

BUISSON, Ferdinand (dir.). Dictionnaire de pédagogie et d'instruction primaire. Paris: Hachette, 1878-1887.

BUISSON, Ferdinand (dir.). Nouveau dictionnaire de pédagogie et d'instruction primaire. Paris: SHE/INRP, 2001. [Edição original 1911].

DELON, Charles. La leçon de choses: théorie et pratique avec un appendice sur la lecture expliquée. Paris : Hachette, 1887.

DUBOIS, Patrick. O dictionnaire de pédagogie et d'instruction primaire de Ferdinand Buisson (1878-1887 e 1911). História da Educação. Pelotas: Asphe, v. 5, n. 9, 2001, p. 59-76.

DUBOIS, Patrick. Le dictionnaire de F. Buisson et ses auteurs (1878-1887). Revue Histoire de l'Éducation. Paris: INRP, n. 85, 2000, p. 25-47.

DURANDET, Daniel. Les livres de nos cartables. Paris: Editions, 2006.

FELDMAN, Daniel. Imágeneas en la historia de la enseñanza: la lámina escolar. Educação \& Sociedade, Campinas, v. 25, n. 86, 2004, p. 75-101.

HAYAT, Pierre. Notes. In : BUISSON, Ferdinand. Dictionnaire de pédagogie et d'instruction primaire (extraits). Paris: Kimé, 2000, p. 244-249.

JODELET, Denise. Representações sociais: um domínio em expansão. In: JODELET, Denise (org.). As representações sociais. Rio de Janeiro: Uerj, 2001, p. 17-44. 
KAHN, Pierre. La leçon des choses: naissance de l'enseignement des sciences à l'école primaire. Villeneuve d'Ascq (nord): Presses Universitaires du Septentrion, 2002.

RENONCIAT, Annie; SIMON-OIKAWA, Marianne (dir.). La pédagogie par l'image en France et au Japon. Rennes: Presses Universitaires de Rennes, 2009.

SCHELBAUER, Analete R. A constituição do método intuitivo na Província de São Paulo (1870-1889). São Paulo: USP, 2003. 350f. Tese (doutorado em Educação). Programa de Pós-Graduação em Educação, Universidade de São Paulo.

SCHELBAUER, Analete R. O método intuitivo e lições de coisas no Brasil no século 19. In: STEPHANOU, Maria; BASTOS, Maria Helena Camara. Histórias e memórias da Educação no Brasil. v. 2, século 19. Petrópolis: Vozes, 2005, p. 132-149.

TEIVE, Gladys Mary G. Uma vez normalista, sempre normalista: cultura escolar e produção de um habitus pedagógico (Escola Normal Catarinense 1911-1935). Florianópolis: Insular, 2008.

VALDEMARIN, Vera T. Estudando as lições de coisas: análise dos fundamentos filosóficos do método intuitivo. Campinas: Autores Associados, 2004.

VALDEMARIN, V. T. Lições de coisas: conceito científico e projeto modernizador para a sociedade. Cadernos Cedes. Campinas: Unicamp, v. 52, 2000, p. 74-87.

MARIA HELENA CAMARA BASTOS é professora no Programa de Pós-Graduação em Educação da Pontifícia Universidade Católica do Rio Grande do Sul. Pesquisadora do CNPq e bolsista Capes (2010-11) em estágio pós-doutoral no Service d'Histoire de l'Éducation de l'INRP (Paris-França).

Endereço: Rua Felicissimo de Azevedo, 770/601 - 90540-110 - Porto Alegre - RS Brasil.

E-mail: mhbastos@pucrs.br.

Recebido em 10 de abril de 2012.

Aceito em 26 de agosto de 2012. 


\section{CONFÉRENCE SUR L'ENSEIGNEMENT INTUITIF ${ }^{12}$ PAR FERDINAND BUISSON (31 DE AGOSTO DE 1878) ${ }^{13}$}

Essa reunião é a última da série de conferências pedagógicas as quais o Senhor Ministro, referindo a voz da Assembléia, os fez vir de todos os pontos da França.

Digo-lhes como é pesada a minha missão.

Chamado a tomar a palavra diante de tantos professores eminentes, como fechar dignamente tais lições? Como escapar das comparações que podem me reprovar? Necessito, vocês o sentem como eu, de toda sua benevolência e de alguma coisa mais. Além de sua benevolência, combinada à dificuldade do tema que me atribuiu a Comissão tenho um embaraço e uma inquietude que não procurarei dissimular.

Portanto, vou Ihes dizer? A Comissão teve razão de me colocar no último lugar, como para servir de fechamento, com uma recapitulação das excelentes lições que vocês ouviram o estudo do ensino intuitivo. Isso é uma das questões de métodos mais gerais, a qual interessa ao mais alto grau de todos os setores do ensino primário, o qual naturalmente foi indicado como lição final. O que farei, por assim dizer, será um resumo das diversas aprendizagens que vocês recolheram, talvez somente as repetindo, mas não as enfraquecendo.

Vamos, vocês verão, adentrar senão em um terreno escaldante, - que não tem relação propriamente com a pedagogia, - ao menos em um terreno semeado de espinhos. A natureza da intuição, seu papel, o escopo e o verdadeiro caráter do método intuitivo, são os pontos sobre os quais os espíritos estão ainda muito divididos. Não sei se terei a felicidade de partilhar com todas as minhas apreciações; mas peço a permissão de explanar com toda liberdade as opiniões que creio justas, convencido de que o acordo ou o choque de idéias entre pessoas que se ocupam das coisas de seu ofício, resultam em algum bem.

Inicialmente, daremos a palavra aos partidários absolutos do ensino intuitivo, aqueles que abraçam o mesmo amor ao método e aos processos do ensino pela intuição. Para entender, a França quase sozinha se manteve no velho sistema de educação e de ensino, sistema que em outra época teve razão de ser, mas que, depois do século 18 , perdeu seu crédito em outros povos ou mais, diremos, em quase todos os povos civilizados. Por tudo, com exceção da França, o método escolástico muito pesado,

\footnotetext{
${ }^{12}$ BUISSON, Ferdinand. Conférences dédagogiques faites aux instituteurs délégués à l'Exposition Universelle de 1878: Conférence sur l'enseignement intuitif. In: BUISSON, F. Conférences et causeries pédagogiques. Paris: Ch. Delagrave \& Hachette, 1888, p. 3-31.

13 Tradução de Maria Helena Camara Bastos.
} 
pedante, seco, desapareceu; uma grande idéia apareceu nos espíritos e penetrou nas escolas. Essa idéia é que todos os conhecimentos vêem dos sentidos, por conseqüência, toda instrução deve ser feita pelos sentidos. Nada mais simples. Citemos os nomes, todos grandes nomes, de Locke e Condillac, depois de Rousseau, Pestalozzi, Basedow, Campe, Froebel, Diesterweg e todos os pedagogos que fazem a honra da Alemanha, depois de três quartos de século. Todos esses e mais os suíços, os americanos, os italianos, que sabemos ainda? Todos que citamos o aplaudem, reconheceram que o ensino que convém à escola popular é essencialmente esse, que se faz pela via da demonstração sensível, visível, palpável, ensino pelos olhos. É esse modo de ensino que dá à escola moderna duas características distintas: por um lado, certo aspecto amável e quase alegre, estudos que fazem quase jogando, uma escola onde o aluno se diverte, uma educação em que o esforço e a pressão são banidos; por outro, a segunda característica, não menos impressionante, é que todo o ensino é prático, útil: ensinamos aos alunos aquilo que poderão utilizar. Para quê as teorias em gramática, em aritmética? Para quê as regras gerais, as considerações científicas que temos o prazer de irritar qualquer dos estudos primários, depois o cálculo até a geometria? Daremos, então, uma boa gramática usual, a aritmética comercial, a geografia comercial; em síntese, todo um ensino simples, utilitário, positivo.

Vocês todos já leram esses termos ou termos parecidos, esse panegírico do ensino pelos meios sensíveis e pelos "procedimentos rápidos". Cabe agora vermos em que é fundada e legitimada essa tese.

É perfeitamente verdadeiro que, depois do século 18, procuramos e conseguimos simplificar, popularizar o ensino; que essa reação contra o ensino escolástico era uma necessidade; é perfeitamente verdadeiro que Rousseau, por exemplo, demonstrou o que fez começando toda educação pela educação dos sentidos, disse uma das suas verdades as quais ninguém hoje pode mais se opor. Observemos somente (sem insistir, pois não é o lugar) que antes de Rousseau, precisamente na França, Montaigne, Rabelais, Fénelon, Rollin - eu me limito a citar seus nomes, para que tenha presente o espírito dos cidadãos que o puderam fazer - que protestaram contra o abuso da abstração no ensino e exigiram para as crianças outra coisa que a "ciência livresca".

Mas, depois de ter reconhecido a legitimidade dessa revolução pedagógica que tende a substituir, como dissemos, o realismo ao verbalismo, vou marcar os limites que não se pode transpor.

É suficiente, para fazer vocês verem, lembrar o que deve ser o ensino primário. Se solicitamos ao professor primário dirigir a educação ao coração, à inteligência, ao caráter, o problema será muito mais simples. Mas, sem permitir negligência com a educação, exigimos, e é mesmo o resultado mais aparente do seu ensino, que faça que seus alunos adquiram uma instrução determinada. Ele deve fazer com que aprendam certo número de conhecimentos instrumentais, porque sem ser para eles mesmos as ciências, são o instrumento indispensável de comunicação com seus semelhantes. Ler, escrever e contar era para os nossos pais toda a bagagem da instrução popular; sei que não pretendemos suprimir nenhuma dessas três longas aprendizagens. Longe disso, acrescentamos vários outros objetos de ensino que são também muito necessários, me apresso em dizer - a gramática, a geografia, a história, o canto, o desenho, e acrescentemos, espero, um estudo que lhes foi muito recomendado e que a maioria dos países reconheceu, depois 
de longo tempo, como parte integrante do ensino primário: noções de história natural. Depois de cinqüenta anos, o programa não para de se enriquecer e hoje, longe de tentar o reduzir, solicitamos ainda que o estendam.

Todos conhecimentos, se elementares como supomos, poderão ser adquiridos pelos alunos, por um ensino sempre fácil, com a ajuda de imagens, de quadros, de aparelhos que os deixam com vontade de olhar, ou sob a forma de conversas agradáveis, de histórias divertidas que nós apresentamos hoje como o ideal da educação? Eu não creio.

Para ensinar e, sobretudo, para ensinar eficazmente tantas coisas em pouco tempo, há necessidade de conhecermos através de uma prática constante: colocar a criança, e, no lugar de deixá-lo perambular, passemos à expressão sobre o caminho da ciência, isso o forçará a avançar. Vocês são obrigados pela natureza das coisas, pelo entendimento dos programas que impusemos, por meio de exames.

Dissemos aqui mesmo com uma grande autoridade: Por que atormentar seus alunos com tantas dificuldades gramaticais, tantas regras que verdadeiramente não lhes são indispensáveis? Vocês poderão me responder: Isso começa pelos examinadores! Vocês podem pedir melhor, tenho certeza, que apressar a tarefa das crianças e a sua ao mesmo tempo; mas vocês estão seguros, por exemplo, que as comissões de exame serão sempre a opinião de eminente professor que lhes disse outro dia espiritualmente: Para que esgotar as crianças com todas as sutilizas de ortografia de vinte e de cento, de todas, mesmo, qualquer e das regras do particípio passado seguida de um infinitivo? Isso foi talvez uma inovação salutar; mas qual mestre ousará correr o risco que seus alunos se apresentam ao exame de certificado de estudos? Se há uma reforma a ser feita nesse sentido, não é a vocês que vou pedir, mas àqueles dos quais vocês dependem e do que depende a instrução primária.

Aliás, qualquer sábia redução à excessiva dificuldade de certas partes do programa, sempre resultará ser uma quimera esperar que a instrução nas escolas se dê e se receba como jogando. Dissemos mais, essa quimera não é desejável. Se chegarmos um dia a esse resultado, que a idéia de esforço, dificuldade e trabalho venham a desaparecer da escola, esse dia a mesma idéia estará bem perto de desaparecer também da sociedade. E uma sociedade em que a lei do trabalho e do sofrimento torna-se insuportável, é uma sociedade que amadurece hoje pela anarquia e amanhã pelo despotismo.

Mas não nos limitemos com essa resposta sumária. Vejamos mais de perto em que consiste o método intuitivo, como aplicamos antes, como podemos aplicar entre nós, e se é verdade que o que se pretende, em filosofia como em pedagogia, é reduzir tudo aos sentidos.

A palavra intuição, que não é ainda de uso corrente, é uma palavra perfeitamente formada, que aparece na nossa boa língua ${ }^{14}$; e, como todos que exprimem um fato muito simples, é mais fácil de compreender do que de definir. É aqui que me engano, é na Sorbonne que fez sua entrada no ensino oficial, em torno de 1817, com todo o prestígio que tinha então a palavra de $\mathrm{M}$. Cousin. A intuição é um ato o mais natural e o mais espontâneo da inteligência humana, pelo qual o espírito compreende uma realidade, sem esforço, sem intermediário, sem hesitação. É uma "percepção imediata", que se faz com

\footnotetext{
${ }^{14}$ Todo homem é intuitivamente convencido da verdade dessa proposição: dois é mais que um (Boulainvilliers). Locke chama com alguma razão conhecimento intuitivo aquele que se forma no primeiro e no mais simples olhar do espírito (Le Pére Buflier).
} 
um golpe de olhar de qualquer forma. Trata-se de uma realidade material? Os sentidos os percebem também: é o caso mais simples, o mais familiar, o mais fácil de reparar. Tratase de uma idéia, de uma verdade, de realidades, enfim que não caem sobre os sentidos? Dizemos ainda que compreendemos intuitivamente nossas mentes apenas quando ocorrer afirmá-la e a compreendê-la, sem a ajuda do raciocínio e da discussão. Nossos procedimentos por intuição ocorrem toda vez que nosso espírito, seja pelos sentidos, seja pelo julgamento, seja pela consciência, conhece as coisas com o grau de evidência e de facilidade que apresenta ao olho, à visão distinta de um objeto. Assim a intuição não é uma faculdade à parte, não é qualquer coisa de estranho ou novo à alma humana. É a alma humana que percebe espontaneamente aquilo que existe nela ou ao redor dela.

Três espécies de intuições ou mais exatamente três domínios nos quais a intuição pode se exercer sob diversas formas, mas sempre com as mesmas características essenciais: a intuição sensível é aquela que faz parte dos sentidos; a intuição mental propriamente dita, aquela que se exerce pelo julgamento, sem intermediário nem de fenômenos sensíveis nem de demonstração em regra; enfim, a intuição moral, aquela que se dirige ao coração e à consciência. Essas três intuições, ou melhor esses três nomes da intuição englobam as diversas parte da atividade intelectual do homem ao estado instintivo, para assim dizer. Julgar por intuição é quase julgar por instinto.

Depois dessa rápida exposição, a seguir veremos em que a definição francesa de intuição difere daquela dos filósofos alemães, e apresentarei que o método intuitivo da qual deriva não é aquele que atende a todos os sentidos. O uso que prevaleceu na Alemanha, apesar das altas e notáveis exceções, é de tomar a palavra intuição (Anschauung) no sentido da intuição sensível, e, por conseqüência, faz consistir o ensino intuitivo naquilo que denominamos entre nós de ensino por aspecto ou pelos olhos. Nós, ao contrário, sem diminuir a parte desse gênero de ensino, cremos que a intuição tem outra função a oferecer.

O método intuitivo, tal como compreendemos, é aquele que todo o ensino faz apelo a essa força sui generis, a esse golpe de olho do espírito, à essa espontaneidade da inteligência em direção à verdade. Consiste não pela aplicação de um ou de outro procedimento, mas na intenção e no hábito geral de agir, de deixar agir o espírito da criança em conformidade com o que nós chamamos até agora dos instintos intelectuais.

O método intuitivo é aquele que diz ao mestre: Sua tarefa torna-se dia após dia mais pesada e mais complicada. Para mudar, ele pode vos ajudar. Como? Por bons livros, bons procedimentos, bons programas? Sim, sem dúvida, mas mais ainda pelo aluno, ele mesmo. É seguramente seu melhor auxiliar, seu colaborador mais eficaz. Faça que não se submeta à instrução, mas que tenha uma parte ativa, e terão resolvido o problema. No lugar de ter de fazê-lo avançar arrastado pela mão, marcharão alegremente consigo.

O método intuitivo não é outro segredo; ele trata a criança como um ser que tem em si mesmo o instinto do saber e todas as faculdades necessárias para adquiri-los; ele se aplica em deixar a natureza fazer o que seja possível. Sem dúvida a natureza não basta sempre, mas ao menos não a desencorage; é o que distingue a educação da domesticação: uma desenvolve na realidade as disposições naturais, a outra só obtém resultados aparentes com a ajuda de procedimentos mecânicos.

1. Intuição sensível 
A aplicação mais comum do método intuitivo na ordem do sensível é bem conhecida no ensino primário, é a lição de coisas.

E impossível de falar sobre a lição de coisas sem reportar imediatamente às contribuições de Pestalozzi. Vocês lembram tudo que foi contado, por testemunhas oculares de suas visitas ao Instituto de Yverdon, sobre o tapete esfarrapado sobre o qual o velho mestre mostrava aos seus alunos as figuras geométricas: "Que vocês vêem aí? Perguntava a um deles. Eu vejo um buraco no chão; tu vê uma fenda na tapeçaria. Repetem isso". E toda a classe repete: "Eu vejo uma fenda na tapeçaria. Como ela é? Ela é larga? - Não. - Ela é ... o contrário de largo?". Eles não sabem a palavra, ele os ensina: "Eu vejo uma longa e estreita fenda na tapeçaria... E o que vocês vêem através? - Através da longa e estreita fenda da tapeçaria eu vejo o chão". E assim se prolongava o exercício que, não é preciso dizer, se tornava singularmente fatigante. As crianças, apesar do respeito que tinham por Pestalozzi, deixavam e acabavam por escutá-lo com um ouvido distraído. Bem! Se estranhas e se pobres que sejam essas lições de coisas no início, vocês não podem deixar de rir; se souberem que essa cena que contamos recontamos também que alguns dias, pouco depois de acabar a lição, um dos seus alunos encontra Pestalozzi no fundo do seu jardim com a cabeça entre as mãos, chorando como uma criança e se aproximando com amargura por não saber como melhor fazer!

A antiguidade nos ensinou a respeitar o nobre delírio de um sábio que descobriu uma lei física, se lançando como um louco na cidade e escrevendo: "Eu descobri!". Não encontramos nada de mais nobre e mais respeitável ainda na desesperança desse velho, que dedicou sua vida de pesquisador para encontrar um meio de tornar o homem melhor pela educação; escreveu em um acesso de dor: "Eu não descobri!". É por isso que Pestalozzi é Pestalozzi. Não é por tal ou outro procedimento, é pelo método; dizendo melhor, não é pelo método, é pelo coração. A palavra de Vauvenargues em nenhuma parte são mais verdadeiras que em pedagogia: "Os grandes pensadores vivem do coração".

Aliás, Pestalozzi não estava a procura daquilo que conseguiu fazer. Ele compreendeu perfeitamente e fixou os pontos essenciais da reforma; estava plenamente certo, podemos dizer na primeira de suas máximas: as coisas antes das palavras, a educação pelas coisas e não a educação pelas palavras.

É uma inspiração de gênio; felizmente não tardou a se fixar, materializar; a letra matou o espírito e desde lá há uma longa história, que não os contarei, das transformações sucessivas do ensino intuitivo na Alemanha. Sem repassar por todo o périplo que foi submetido o sistema, depois dos primeiros pestalozzianos até os nossos dias, procuremos nos dar conta do que deve ser a lição de coisas: aquilo que se entende pelo espírito e não tenho dificuldade em imaginar os procedimentos adequados. Não esqueçam que somos o país de Descartes, e que, como ele, no lugar de encobrir com a esterilidade abundante da erudição, sempre temos o direito de reconstituir os recursos e de estudar diretamente as coisas mesmas à luz de nossa razão.

Qual é o objetivo da lição de coisas: - É de ensinar aos alunos antes de tudo a observar as coisas, depois as nomear, e, enfim, as comparar.

Nada mais simples e mais claro. Pestalozzi também distinguiu os três elementos da intuição: o número, a forma, o nome. Quantos objetos? Como são eles? Como se chamam? 
As crianças necessitam que Ihes exercitem assim a observação? Aqueles que estão em dúvida deveriam reler as páginas em que Rousseau mostra que a criança deixada a sua própria sorte não sabe observar. "Exercer os sentidos, diz ele, não é apenas fazer uso, é aprender a bem julgar por si e, em algumas vezes, a bem sentir: se não sabemos nem tocar, nem ver, nem entender, como nós apreendemos". Permitam-me citar um testemunho mais moderno, muito interessante para vocês, pois não foi escrito em sua intenção? É uma página de Alphonse de Candolle.

"A qualidade de saber observar, diz Candolle, é indispensável para assim dizer para todo mundo. Nós somos dotados desde a nossa infância de uma capacidade remarcável. Que fazem então as escolas para desenvolver essa preciosa faculdade? Quase nada. Ao contrário, o que faz para a entravar? Muito. Para provar, invoco o testemunho daquele que, como eu, ensinou as ciências naturais a jovens de 18 a 20 anos. Diz como é freqüente ver os alunos, as vezes os melhores para o conjunto de estudos, que não sabem identificar as coisas mais visíveis em um objeto material. Para melhor julgar, solicita a um deles para descrever uma planta em voz alta. É comum que não olhem para o objeto que está entre suas mãos. Procuram na cabeça e lembrando a observação, não sabem ver se as folhas estão em frente uma das outras ou situadas em alturas diferentes ao longo do caule.

Com cinco ou seis anos eles talvez tenham uma melhor visão, mas depois de muitos anos ocupados unicamente das coisas abstratas ou internas: gramática, palavras de várias línguas, cálculo, história, religião, poesia. Se aprenderam alguma coisa dos fatos da história natural foi nos livros. Se olharam por orientação de um professor qualquer detalhe de forma, foi nas lições de desenho, e ainda copiando os modelos.

Os primeiros estudos, em que o objetivo lógico deve ser o de desenvolver todas as faculdades naturais da criança, se fazem quase sempre com o sentido de desenvolver a reflexão abstrata, a memória e a imaginação. Esquecemos a observação. Esquecemos também que a faculdade de observar não é só o fato de olhar, mas de gravar na memória, de comparar e de refletir para tirar conclusões que sejam verdadeiras.

Então observar é uma operação por sua vez dos olhos e do espírito muito complicada. Ela não aparece à criança rapidamente; ao contrário. Ela não se opõe a nenhuma de suas faculdades, se não houver a imaginação que necessita. Ela favorece a memória, a atenção e o raciocínio. Se os professores a temem, é porque não a compreendem ou não sabem como a dirigir. Os olhos se dirigem às excursões e, posso dizer, à gazeta da escola, ajudam o aluno a não perder absolutamente o uso de seus olhos. Se ele vai ao campo, não perde ocasião de observar; mas a cidade, sobretudo em uma grande cidade, é outra coisa: o besouro nativo é o único animal que ele pode examinar e ainda somente a cada quatro anos!".

Essa espiritual crítica da educação dos colégios é também aplicável à escola primária. Que vocês sabem melhor? Que sacrifício não fazem para conseguir que o aluno olhe aquilo que vê todos os dias? Para conseguir na infância que essa preguiça das faculdades de observação seja como uma segunda natureza. É por isso que é sempre difícil recolher um testemunho preciso sobre um fato simples. Pergunte para muitos Parisienses qual espécie de árvore é plantada nas ruas em que caminham todos os dias, 
eles não saberão lhes dizer, pois jamais as observaram ${ }^{15}$. E, o que é mais surpreendente ainda, o camponês, sobre as coisas mesmo da natureza não tem os olhos mais abertos, não tem a idéia de examinar curiosamente os objetos que estão no seu entorno, ou melhor, não sabe o nome que os designa e não os procura.

É essa falta de curiosidade, verdadeira ferrugem da inteligência, que a educação deve combater antes de tudo. "Deve, dizia Fénelon the fazendo alusão, deve remexer rapidamente todos os recursos da alma da criança para lhe tirar desse adormecimento".

Bom! A lição de coisas é precisamente o exercício imaginado para despertar e para aguçar esse sentido de observação. Em todas as idades, em todos os graus de ensino, ela nos coloca em presença das coisas, nos força a vê-las, tocá-las, distingui-las, medilas, compará-las, nomeá-las, para conhecê-las, do que para ouvir dizer.

Se esse é o objetivo essencial da lição de coisas, qual procedimento convém aplicar? Evidentemente aquele que seja seguramente o exercício mais proveitoso "observação pelos olhos e pelo espírito".

Há dois sistemas: um faz a lição de coisas um exercício a parte, com uma hora reservada no programa, seguindo um plano sistemático e um formulário anteriormente elaborado; o outro, ao contrário, coloca a lição de coisas por tudo e em tudo, não a inscreve como uma lição distinta. Qual dos dois sistemas é o melhor? Vou fazer vocês julgarem.

Abram um desses livros de lições de coisas ou manuais de ensino intuitivo, já numerosos na Alemanha e que começam a aparecer entre nós. Pego um, não qualquer um, mas um dos melhores em francês, segundo meu conhecimento, cujo o autor é diretor de escola normal com longa experiência, muita instrução e ainda muito devotamento. Vejamos o que nos oferece como "modelo para imitar livremente", para fazer fazer, "de viva voz primeiramente, depois com pequenas composições escritas, com a descrição dos objetos pelos alunos de 9 a 12 anos":

A descrição de cada objeto se fará geralmente depois do seguinte plano:

$1^{\circ}$ Espécie do objeto (classificação, definição);

$2^{\circ}$ Partes do objeto;

$3^{\circ}$ Qualidades do objeto: a) qualidades gerais; b) qualidades das partes;

$4^{\circ}$ Natureza do objeto e de suas partes;

$5^{\circ}$ Utilidade do objeto (seus atos);

$6^{\circ}$ Fábrica que o fabrica.

Esse plano é o mesmo a seguir nas três primeiras partes do curso: o professor e o aluno devem gravar de memória!

A descrição deve ser feita inicialmente sobre um indivíduo particular, depois sobre a espécie, como faremos a seguir:

I. Minha régua

$1^{\circ}$ Minha régua é um objeto escolar.

${ }^{15}$ Bruyère pertinentemente já disse: "Caminhamos na cidade com uma indiferença das coisas rurais e campestres. Distinguimos com esforço a planta cânhamo que produz o linho e o trigo formando com o centeio, um ou o outro como uma mistura de cereais... Um grande número de burgueses conhece o mundo, suas origens, seus progressos, suas capacidades e liberdades". (Caracteres, fim do capítulo VII). 
$2^{\circ}$ Ela é sem partes.

$3^{\circ}$ É um prisma: tem quatro lados retangulares, duas pontas quadradas, quatro arestas longas e oito curtas.

$4^{\circ}$ Minha régua é em madeira.

$5^{\circ}$ Ela serve para traçar, isto é, fazer as linhas na minha ardósia e no meu caderno. Também pode servir para desenhar.

$6^{\circ}$ Minha régua é feita pelo carpinteiro.

Essa descrição deve ser exercida até que o aluno possa fazer correntemente.

O professor destacará que a régua não é só um objeto da escola, mas que tem uso nos escritórios e em outros lugares, a régua é um móvel.

\section{A régua (em geral)}

$1^{\circ} \mathrm{A}$ régua é um móvel.

$2^{\circ}$ Ela é sem partes.

$3^{\circ}$ A régua é um prisma. Tem também réguas planas com acabamento de dobradura. A régua é reta, lisa, branca, escura, cinza ou negra.

$4^{\circ} \mathrm{A}$ régua é em madeira, em ferro, em latão ou em prata.

$5^{\circ}$ Servimos da régua para fazer linhas, para desenhar, para cortar o papel.

$6^{\circ} \mathrm{A}$ régua em madeira é feita pelo carpinteiro, a de metal pelo mecânico.

Podemos descrever da mesma maneira os seguintes objetos simples: a linha, a bengala, a vara, a tábua ou prancheta"16.

É possível que em determinados casos, para certos alunos, em outros povos, exercícios desse gênero tenham sua utilidade, sua razão de ser; não creio que convenham para nossos alunos. Parecem ter inconvenientes que o compõem, apesar das vantagens que lhe são atribuídas.

Primeiramente essa descrição minuciosa dos objetos, não os ensina a observar. Enumerar, descrever meticulosamente os objetos, não é sempre o meio de fazer olhar melhor. Os detalhes mascaram o conjunto. Depois, não é para ver tudo das coisas, sobretudo deve sair do espírito das coisas; e nada prepara melhor do que o hábito do inventário; ou, a lição de coisas que critico é mais que um inventário ou catálogo classificado em rubricas que determinam certo número de respostas secas às questões sem interesse.

Existe um meio melhor de aprender a julgar? Eu não penso. A forma estereotipada dessas categorias sempre passadas em revista na mesma ordem e forçando os mesmos termos, não é outra coisa que uma receita para pensar artificialmente. Tomem o melhor fato desses conjuntos de exercícios de intuição. Os desafios de ler duas páginas seguidas sem perceber a diferença que há entre o pensamento produzido como em uma forma e pelo procedimento sistemático, e o pensamento vivo e verdadeiro. Esses julgamentos de fato têm a estrutura exterior dos julgamentos espontâneos que as crianças expressam todos os dias; que falta é... o que esta faltando em uma flor artificial pode ser em um campo de flores.

\footnotetext{
${ }^{16}$ Plan d'études et leçons de choses de six à sept ans, par Jules Paroz, directeur de l'école normale libre de Paseux, prés Neuchatel. $2^{\circ}$ étidion. Paris: Fischbacher, petit in- $8^{\circ}, 160$ pages.
} 
Enfim, este exercício ensina ao menos a falar? É, creio, o mérito ao qual pode ao menos pretender. Podemos ensinar palavras novas às crianças, entender seu vocabulário. Uma maravilha, e não é uma coisa difícil. Mas falar, não é enfiar as palavras que podem, à rigor, se deixar juntar umas com as outras. Qual é a criança de seis anos que se atreve a encadear em uma mesma frase todos os adjuntos adnominais que pode tirar do nome de uma coisa ou animal? Vocês os fazem dizer:

A mesa é pequena, marrom, nova, sólida.

As árvores podem ser altas, baixas, ramificadas, pontiagudas, com folhas, verdes, amareladas, floridas, secas, direitas, inclinadas.

As abelhas são vivas, úteis, corajosas, laboriosas, pretas, peludas, com asas. ${ }^{17}$

Qual relação existe entre essas qualidades uma com as outras? Vocês desejam que as crianças façam frases como nós fazemos versos em latim com a ajuda dessa recordação preciosa, o Grandus ad Parnassum, onde se descobre para cada substantivo uma lista de uma dezena de epítetos e uma meia dezena de sinônimos a escolher de acordo com a necessidade do verso? Se, infelizmente, a criança se deixa fascinar por esses exercícios, descobrindo as frases mais corretas ao gosto das quais façam a felicidade de todos os estudantes: "O coelho é um animal tímido.... e nutritivo".

Não há perigo, dirão, e convém. O natural assume. Mas então para que serve essa nomenclatura das qualidades, das partes, dos usos, das formas e de todas as outras categorias que a lógica distingue em um objeto qualquer? Vocês não vêm que na maior parte do tempo, pelo prazer de responder às questões que o exercício comporta, que fazem o aluno falar para nada dizer? Vejam uma lição sobre o pombo: levamos o pombo para a sala de aula, é muito bom, e o mostramos aos alunos. A primeira coisa que eles de fato dizem, é: "o pombo tem uma cabeça". E toda a classe repete em coro: "O pombo tem uma cabeça". Pode ser que os pequenos alunos alemães tenham prazer de proclamar essa verdade, mas entre nós, se o professor ensina dessa maneira, os alunos, justamente os pequenos, crêem que fazem pouco deles, eles irão retribuir, podem crer.

Não podemos, portanto, ser mais infantis que a infância, mais ingênuos que a ingenuidade. A forma natural da linguagem das crianças pequenas, quando vocês lhes mostram um pássaro, não é para dizer patetamente: "1º Esse pássaro tem cabeça; $2^{\circ}$ esse pássaro tem duas patas; $3^{\circ}$ esse pássaro tem duas asas", é de se exclamar "Oh! Linda cabeça! Oh! como tem belas patas, belas penas, grandes asas!". Não tentemos refazer o cérebro das crianças. Não são autômatos pensantes e falantes, são crianças, amanhã homens como nós. Eles necessitam aprender a falar, a julgar, a olhar, mas não precisam para isso fazer, por assim dizer, exercícios prussianos no domínio do pensar.

Esses são os motivos que nos inspiram, já há muito tempo, uma reação contra o abuso desses pretensiosos exercícios de intuição nos quais não há nada de intuitivo. Uma mulher com um grande bom senso e coração, Madame Pape-Carpantier, que recusa se dobrar a essa disciplina intelectual muito árida e muito minuciosa, tem procurado fazer da lição de coisas francesa uma língua viva, uma lição falada e pensada. Mas, se remarcáveis são os exemplos que ela nos deixou, ela mesma não deseja que peguemos servilmente como modelos e que os apliquemos em qualquer situação.

\footnotetext{
${ }^{17}$ Mesma obra.
} 
A melhor lição de coisas é aquela que o mestre faz, aquela em que descobre um tema, os detalhes, o tom, a gradação, a forma e o plano, enfim, seguindo a idade e os conhecimentos de seus próprios alunos. Somente ele pode perceber as verdadeiras necessidades de seu jovem auditório. Se a lição de coisas não é indefinitivamente variável, flexível e com movimento, como a palavra e o pensamento, ela não é que um artigo no programa, um fardo a mais para a jornada do mestre e do aluno. Para que ajude a escola com a boa influência que tem, faça que seja a alma de todo o ensino; que entre como o levedo na massa, para animar, transformar, aquecer a pesada e fria massa de estudos técnicos os quais o ensino primario nunca dispensa.

Não desejo por isso, - desejo vos confessar e me permitam dizer com toda a sinceridade -, ver a lição de coisas começar e terminar em uma hora fixa. Que ela se faça ora na ocasião da lição de escrita ou de leitura, ora a propósito de um ditado, de uma lição de história, de geografia, de gramática, etc. Que se faça em dois minutos ao contrário de vinte, ela vale igual; seguidamente não consistirá em uma série de questões numeradas, mas em uma questão viva, precisa, clara, que provocará uma resposta semelhante; frequentemente será um esquema no quadro negro que será melhor que toda uma descrição. Um dia a lição de coisas será uma visita ao museu local, a um estabelecimento industrial, a um monumento histórico; ou uma caminhada topográfica, ou um passeio no bosque, uma coleta de insetos ou plantas. Outra vez, na classe, serão os exercícios tirados fora dos livros: pedimos às crianças, por exemplo, de trazer amanhã folhas de duas árvores que eles talvez jamais pensaram em distinguir, a pêra e a macieira, o pinheiro e a árvore de natal, ou outras espécies de alamos; ou também pedras, minerais, amostras de madeira, produtos manufaturados que se encontram no país, mas que se encontram também no pequeno museu escolar; ele pode pegar qualquer coisa no museu escolar, e não será lamentável dizer que cada geração escolar é obrigada a reconstituir por assim dizer um novo, por suas próprias pesquisas; o grande proveito a tirar desses pequenos museus de lições de coisas, não é os ter, mas de os fazer.

Em outros momentos, - e devemos retornar seguidamente, pois é uma noção que vale a pena gravar no espírito das crianças -, devemos os exercitar a se orientarem com ou sem a bússola, na busca do sol ou de uma estrela polar. Formaremos, dessa forma, seu olhar para a medida e a avaliação aproximativa dos comprimentos, das distâncias, das superfícies, dos pesos, dos volumes. Existem alunos nos liceus, muito fortes em matemáticas, que não são capazes de estimar a capacidade de um campo, o peso de um saco de trigo, ou o volume de uma pilha de batata. Gostaria que um aluno não saísse da escola primária sem ter o olho e o toque infalíveis, ao menos muito exercido por essas medidas intuitivas; é uma das condições para que o desenho se generalize nas escolas.

Mais tarde, quando as crianças tiverem o espírito despertado, poderemos passar da observação pura e simples dos objetos à observação seguinte, regular, de pequenas séries de experiências, que exigem o método: na primavera, por exemplo, podemos os fazer seguir e anotar dia a dia em um aquário ou no mar próximo as maravilhosas séries de transformações dos batráquios mais comuns, rãs ou salamandras; há na Suíça pequenas sociedades de jovens, rapazes de doze a dezesseis anos, que com muita delicadeza e paciência fazem observações fáceis de história natural elementar. Num outro ano, ou melhor, muitos anos depois, veremos eles estabelecerem qual ordem, quais datas 
precisas as árvores se cobrem de folhas, de flores, de frutos, e em qual ordem inversa elas as perdem: quantas pessoas se embaraçam em dizer qual é a primeira árvore em que aparecem as folhas, o carvalho ou a castanheira".

Mas cabe ainda mostrar que a lição de coisas exige, para não dizer de outra forma, que o seu tempo e suas forças. Uma só recomendação resume todas as outras: que a lição de coisas não degenere jamais em uma lição de palavras; que seja sempre a coisa ela mesma que faça a lição e não vocês a proporem a coisa. É o que os Americanos chamam object lessons, não é uma lição sobre os objetos, é uma lição pelos objetos eles mesmos.

\section{A Intuição intelectual.}

Qualquer importância que tenha a lição de coisas bem feita, é no meu entendimento a primeira e talvez a mais difícil aplicação do método intuitivo. A educação dos sentidos e a educação pelos sentidos é o começo do ensino intuitivo, mas é necessário que se aplique em seguida aos exercícios da inteligência, aos atos de julgamento. É aí que seu ensino deve ser sobretudo intuitivo, e é aí que está a maior dificuldade em sê-lo.

Vocês lembram a história que Rousseau conta de um Inglês que confiou seu filho a um preceptor e que após alguns anos de educação desejou submetê-lo a um exame. Ele vai ver o filho, o encontra caminhando em uma planície, onde os estudantes se distraem conduzindo uma pipa. O pai passando diz ao filho: Onde está a sombra da pipa? O filho responde sem hesitar, sem levantar a cabeça: "Ela está sobre a grande estrada". Em síntese, diz o Inglês, a grande estrada está entre nós e o sol.

Aqui está um exemplo de intuição intelectual; e essa citação prova, para dizer de passagem, que Rousseau não reduziu tudo aos sentidos, nem Pestalozzi, os quais procuram resumir seu sistema, assinalando seu objetivo "a cultura dos sentidos exteriores é aquela dos sentidos internos". A intuição sensível, de fato não é que a condição de dirigir a intuição intelectual. Ele deve aprender a julgar pelos sentidos, mais precisamente para poder chegar a nos passar os sentidos. A criança que dá essa resposta muito sensível, evidentemente teve uma grande força de abstração; viu a coisa em si mesmo, e não precisou procurar pelos olhos, procedeu de imediato, pela pujança da reflexão, somente com a luz do espírito, e aí está o resultado de uma boa educação intelectual.

Por que é tão difícil desenvolver essa segurança de um golpe de olhar nas crianças? Por que os professores, que impõem tantos esforços para facilitar os estudos de seus alunos, raramente obtêm esse resultado de ver a inteligência das crianças desperta, alerta, em pleno exercício, em pleno movimento? Pode ser que eles se preocupem muito, dizem em sua honra, de proceder no seu ensino com muita lógica possível. Enfim, mesmo que pareça um paradoxo, há duas lógicas: há a lógica natural que é a lógica da criança, e a lógica reflexiva e sábia que é a do adulto. Nós somos mais familiarizados com essa última, nos perguntamos sempre se ela é para a infância, pois ela é para nós mesmos. Vejamos um exemplo ou dois.

Um professor novo ensina uma criança a ler, lembra sempre da famosa máxima: devo ir do simples ao composto: - o simples, diz ele, é um A, um B, um C; então vou ensinar a criança o $A, \circ B, \circ C$, todas as letras, depois as sílabas, as combinações duas a duas, três a três: as letras, depois as sílabas, as palavras, as frases. Essa marcha é mais lógica, ela é progressiva, vai do simples ao composto. - Sim para nós, mas não para a 
criança, porque a criança não se coloca, como nós, no abstrato, não reconhece do que em realidades concretas, sensíveis, em que tem alguma experiência. Os sons pe, a e as letras $\mathrm{P}, \mathrm{A}$, para ela são menos acessíveis que a palavra papa. É que essa palavra desperta uma idéia, representa alguma coisa no seu espírito; uma sílaba tirada dessa palavra, uma letra isolada não lhe diz nada. Não é simples para ele, é vazia de sentido.

Para chegar a decompor a palavra em certo número de sons figurados nas letras, deve fazer um trabalho de análise que a criança nunca fez e nem pode compreender. $O$ ponto de partida, para ela, é o elemento simples, sem decomposição, então a intuição é perfeitamente nítida, é por sua vez a idéia e a palavra papa. Bem! O método de leitura mais intuitivo é o que coloca mais rápido em presença de palavras reais, mais fáceis, mais simples, mas com sentido para ela, de modo que a leitura, em vez de ser uma ação técnica de exercícios vocais, tenha o mínimo de distância da língua falada.

Da mesma forma em geografia. Com a intenção de seguir uma marcha lógica, os professores e os livros começam invariavelmente por dar à criança a definição da terra. Dessa forma, dizemos: "O globo terrestre é dividido em água e terras; as águas compreendem tais e tais partes, as terras outras", e assim por diante. Ordem muito racional para um adulto; mas a criança, que jamais viu um globo terrestre, nem oceano, um estreito, um istmo, um golfo, nem o resto, não descobre o mais simples que vocês acreditam ser. Não é tudo que deve começar do simples ao composto, devemos, sobretudo é o que mais importa, ir do comum ao incomum. Porém, o conhecido é a cidade ou sua rua, é a casa da escola, é o riacho que passa em frente a sua porta, é a subida da estrada onde vai jogar. Comece por isso e guie a intuição, esclareça por analogia, e eles os seguirão sem esforço tão longe quanto vocês desejarem.

Assim, em geografia, leitura, cálculo, em tudo o método intuitivo coloca, de forma completamente contrária ao método didático feito pelos adultos: ele parece ir ao contrário da lógica, porque não trata a criança como homem e o faz marchar no seu passo e não no nosso.

Então, o que é mais necessário, o mais legítimo que essa condescendência do professor, essa apropriação do ensino ao estado mental do aluno? Para nós mesmos, as idéias abstratas e gerais não nos são familiares que por um longo hábito, um longo esforço de concentração intelectual. Nesse momento, vocês me honram escutando-me. Por que? Porque falo de coisas que compreendem e que os interessam. Se eu falasse em hebreu ou chinês, vocês não me escutariam por muito tempo com atenção. O espírito de vocês não sabe onde se coloca, enquanto nesse momento está muito ocupado, trabalha quanto o meu; vocês apreendem uma parte ativa dessa conferência: internamente, aceitam ou rejeitam, aprovam ou censuram as idéias que eu os submeto. A criança também estará atenta, os escutará, senão por muito tempo - ele não pode - ao menos voluntariamente, todas as vezes que compreende, todas as vezes que vocês falarem de temas que eles sabem o sentido, a ligação, o alcance.

Esse aluno, no meio de uma longa recitação de be, a, ba, be, é bé, não segue que a metade, enquanto não perde uma palavra daquilo que seu vizinho diz baixinho, lhe propondo trocar um pião por bolas de bilhar. Essa troca é um negócio sério, que lhe ocupa: ele compreende isso e se agita, para aceitar ou para rejeitar, ele faz um ato de julgamento, de comparação, de raciocínio e de vontade, ao contrário das sílabas que vocês o fazem repetir que são para eles mais ainda que será para vocês um bom discurso 
em chinês. Elas não dirão absolutamente nada à sua imaginação, ao seu coração, a nenhuma de suas faculdades, eles não se interessam absolutamente além de sua orelha. Assim, ele empresta sua orelha quando necessário, mas isso é tudo que você obtem dele. Porém, vocês podem obter outra coisa: fazer eles os escutar com toda sua inteligência.

É necessário que vocês passem seu tempo os distraindo, cativando com histórias, imagens, jogos? Não creio. É suficiente colocar sua inteligência a parte, e isso é próprio do método de intuição. Pela natureza, a criança não é preguiçosa; - é o maior dos suplícios para ela a inatividade, - e digo a inação intelectual: - ele não pode se ocupar por muito tempo na mesma coisa, mas está sempre ocupado com alguma coisa. Do espírito como do corpo, ele precisa se sentir vivo, ágil e crescer. Que se sinta vivo na escola e amará mais a escola. Pergunte mais à sua inteligência, assunto que vocês deixem agir segunda as leis maturais, ele será mais feliz. "De todas as qualidades que vemos nas crianças, disse em alguma parte Fénelon, há uma sobre a qual podemos contar: é o bom raciocínio. Acreditamos sempre nele, para que seja bem cultivado".

Ensaiemos agora pegar uma depois das outras diferentes partes do programa e de mostrar como aplicar o método intuitivo, o meio de "bem cultivar o bom raciocínio" inato na criança, isto é, "de fazer crer nele", fazendo mais e mais cooperar a inteligência da criança à obra da educação?

Recomeçar todas as lições como vocês assistiram, uma apos as outras, como falaram antes mim, usar no seu ensino "os métodos excitantes da inteligência"? Qual objetivo de cada um que foi proposto para a parte do programa que tratamos diante de vocês, senão realizar a palavra de Montaigne: "façam que seus alunos tenham a cabeça bem feita e não bem cheia? E perguntem a si mesmos, não foi recomendado este método de instrução, que toma a criança onde ela está, pergunta sempre antes de aprender a compreender e representar guiada menos pelos processos regulares da lógica didática, que por "essa luz interior que ilumina todo homem que vem ao mundo", a razão natural, outro nome da intuição.

Por fim, devo resumir as regras práticas, as mais essenciais do ensino intuitivo, e o melhor a fazer é os remeter a uma página magistral que terei prazer em reler para vocês:

"Mudar os preceitos e multiplicar os exercícios; jamais esquecer que o melhor livro para a criança, é a palavra do professor; usar sua memória, de maneira flexível, segura, somente como ponto de apoio, e fazer de maneira que o ensino penetre até a sua inteligência, que só pode ser conservada por impressões fecundas; o levar, com questões bem encadeadas, a descobrir aquilo que nós lhe mostramos; o habituar a raciocinar: fazer que descubra, que veja; em uma palavra, ter incessantemente seu raciocínio em movimento, sua inteligência desperta; para isso, não deixar obscuro aquilo que merece explicação, fazer as demonstrações até a figuração material das coisas, todas as vezes que for possível; para cada matéria, tirar os detalhes confusos dos fatos característicos; em todas as coisas, levar para aplicações práticas, úteis, morais; - em leitura, por exemplo, tirar da parte lida todas as explicações instrutivas que comporta; - em gramática, partir do exemplo para chegar à regra despojada das suscetibilidades da escolástica gramatical; retirar os temas dos exercícios não de relatos fabricados ao prazer para complicar as dificuldades da língua, mas de coisas do cotidiano, de um incidente da classe, das lições do dia; inventar exemplos sob o olhar dos alunos, para prender sua atenção, deixe para eles inventarem sozinhos e sempre escrever no quadro negro; - 
transformar todas as operações de cálculo em exercícios práticos retirados dos usos da vida; - ensinar geografia somente com o mapa, entendendo progressivamente a localização da criança, da rua, do bairro, do bairro à cidade, ao município, ao estado, ao País, ao mundo; - em história, sacrificar sem escrúpulos os detalhes de pura erudição para colocar em relevo as grandes linhas do desenvolvimento da nacionalidade, o progresso das idéias sociais, as conquistas do espírito, que são as verdadeiras conquistas da civilização cristã; colocar diante dos olhos da criança os homens e as coisas por pinturas que aumentam sua imaginação e elevam sua alma: tal deve ser o espírito das lições da escola".

Não há necessidade de lhes dizer de onde foi retirado este admirável e substancial resumo das recomendações mais práticas e as mais elevadas: não há que uma pena na França que tenha o segredo desse estilo, e vocês reconheceram.

\section{Intuição Moral}

Preciso explanar muito rapidamente a terceira parte do meu tema. Não é o menor, mas talvez o mais fácil. Posso falar de intuição moral, e não conseguir abordar todo o sujeito, peço permissão de tomar somente dois pontos extremos: a intuição moral aplicada à educação moral e religiosa por um lado, e por outro à educação social e cívica.

Nesse ponto também há matéria à intuição; também há um fundo da alma humana das verdades, que são simples, mas exigem que a instrução primária as faça brotar como verdades do senso comum e das realidades sensíveis.

"Há duas coisas em que a magnitude nos penetra de admiração e de respeito, disse o filósofo Kant: é o céu estrelado em cima de nossas cabeças, e a lei do dever no fundo de nossos corações".

Leve qualquer dos seus alunos mais velhos e mais sérios alguns passos além da última casa da cidade, na hora em que os ruídos do trabalho e da vida quase desaparecem, e os faz elevar os olhos ao céu estrelado. Eles jamais o viram. Eles jamais pensaram sobre os inumeráveis mundos, da ordem eterna e do eterno movimento do universo. Revele a eles essas idéias novas, faça aparecer esse espetáculo do infinito diante dos quais se postaram os primeiros pastores da Ásia e diante dele tremeu como eles o gênio de Pascal.

Abra os olhos ao céu do mundo, que todas as noites nos lembram o que somos, em nos colocando face a face com a verdade do universo. Isso também é uma lição de coisas. - Vocês não sabem a astronomia? - Que importa! Não é ciência, é passar para a alma de seus alunos qualquer coisa daquilo que sentimos. Não sei algumas coisas para Ihes dizer, mas sei em que tom vocês falarão, e é importante; sei como eles os escutarão, sei que muito tempo depois que vocês falaram, eles pensarão sobre aquilo que disseram, e sei também que a partir desse dia, vocês serão, para eles, outra coisa que o professor de ortografia e de cálculo.

Quanta a outra magnitude que nos fala o filósofo, quanto a essa magnitude do dever e da consciência, eles necessitam que vocês o digam com toda a força da intuição que puderem alcançar, contemplar, admirar, adorar? E vocês necessitam Ihes dizer a cada hora da classe, diante de todas as classes, e por sua palavra e pelo seu exemplo, pertence a vocês lhes darem a intuição daquilo que é mais nobre na natureza humana? Certamente que não. Talvez vocês tenham medo, pelo contrário, ele leva longe, traz para 
fora de seu papel. Não creio; jamais admitiria que o professor primário saia de sua esfera, quando dá o melhor de sua alma seja à educação do sentido moral e religioso, que como todos os outros, necessita ser cultivado, seja à instrução cívica, à educação do cidadão. Não admito jamais que sua tarefa termine com o último livro que fechou e com a última lição que ministrou.

Sem dúvida, desde que abordamos esse domínio, a matéria é delicada, as dificuldades são grandes, numerosas: vêm de fora, das circunstâncias, das relações, dos prejulgamentos, das desconfianças, dos diversos obstáculos; são eles que me inquietam menos que para vocês; aquilo que mais me preocupa, sobretudo, é a dificuldade de estar sempre nesse terreno à altura que vocês desejam ser, de falar sempre dignamente dessas grandes coisas, de apresentar às crianças uma imagem suficiente do ideal moral e de manter o culto em sua alma. Disse o ideal, nada menos, e isso não é somente com a instrução popular. Se é um supérfluo, se é um luxo, é o mais necessário de todos, é o único que a democracia não pode se subtrair sem perigo.

Mas há uma regra que vocês podem seguir para evitar se perderem. Em todas as questões morais e sociais, tudo que é intuitivo é de seu recurso e faz parte da educação popular; o resto não é.

Nessas regiões delicadas que contém a religião e a política, nas grandes noções morais, fundamento da educação do homem e do cidadão, há duas partes para distinguir. Uma que é velha como a humanidade, inata em todos os corações, ancorada em todas as consciências, inseparável da natureza humana, e por isso clara e evidente para todo homem; é o estudo, a reflexão, a discussão, da ciência; ela contém as verdades não menos respeitáveis sem dúvida, não menos deslumbrantes, mas também não simples, acessíveis a toda inteligência. É isso a parte sujeita a controvérsias e à paixão, e que em todo o caso exige estudos especiais longos e aprofundados, ela não pertence ao ensino popular: não toque.

Mas a outra, ela lhes pertence e os seus alunos a reclamam. Alega-se que estas questões devem ser reservados, banidas. Respondam que não são mais questões, mas verdades capitais indispensáveis a todas as crianças. As crenças confessionais podem variar, como as opiniões políticas; nisso não vacile, é a intuição do infinito e do divino, da perfeição moral, da justiça, do devotamento; é a intuição dessa grande coisa que jamais pude definir e que por isso não deixo de amá-la menos: a pátria!

Ah! quem não nos fala de proibir todas essas coisas sagradas da educação do povo. Quem não vem nos pedir para fazer do professor primário uma máquina de ensinar, um coração morto, um espírito fugidio e tímido, um ser nulo para o estado, que deixa o medo surpreender uma lágrima nos seus olhos quando fala de sua fé religiosa, ou um turbilhão de emoção na sua voz quando fala da pátria ou da República.

M. Dury disse há um tempo: Formar os homens! Há, para tal uma condição: sejam os homens.

Agora, a medida e a moderação, a prudência, a circunspecção a mais atenta para não exercer nenhuma pressão sobre as crianças, é o primeiro de seus deveres profissionais. Isso é muito familiar para vocês para que eu necessite insistir; mas a preocupação com esse dever não permite que vocês percam de vista outra obrigação, mais essencial para a sociedade e em um tempo como o nosso, é de não impedir que o ensino popular se materialize e decaia. Não é um direito para vocês, é um dever de 
revelar a luz moral aos olhos do coração e da consciência como a do espírito, de não deixar fora de seu ensino nenhuma dessas supremas verdades da intuição em que a alma necessita para viver. E renunciar, será deserdar as crianças!

Sei bem que há pessoas que lhes dirão: "não existe intuição moral, não há verdade fundamental e comum na ordem religiosa, social, moral, política. Nós somos absolutamente divididos, nós somos dois povos, inimigos irreconciliáveis, de tradições diferentes no passado, de aspirações diferentes no futuro; nós não desejamos que nossas crianças sejam alunos sobre uma espécie de terreno comum onde eles desaprendam nos ódios e nas divisões". Sim, infelizmente, há espíritos que pensam assim. Mas há outros, há uma legião de homens na França que passam sua vida a dizer e a provar o contrário, essa legião são vocês. São vocês que têm a missão de serem, no nosso meio, os conciliadores por excelência. E como? Em sendo homens justos de meio? Certo; essa prudência eficácia e banal não exigirá de vocês nem crédito nem ação; isso lhes permite encher com tanto de modéstia quanto de eficiência essa função social, que vocês têm por professar em nome de homens de seitas ou de um partido, mas exclusivamente dos homens do país.

É nisso que vocês elevam e fazem a sua independência: vocês não têm que se misturar com os jornalistas; vocês não pretendem uma influência, um papel, honras! Não: aos outros o presente, para vocês o futuro! Vocês têm nas crianças, a sua melhor parte. Se a França hoje é profundamente dividida, graças a vocês que a França do amanhã será menos; e nessa obra de aproximação todos os bons franceses apóiam vocês.

Se algum vem lhes dizer: "Mas, atenção! tendo com as crianças uma linguagem moral e religiosa, vocês desagradam a algum senhor, que é ateu, temos certeza"; - se outros Ihes dizem o contrário: "Atenção! Falando aos alunos de liberdade, de igualdade, dos princípios de 1789 ou sobre a noite memorável em que os nobres franceses tiraram de suas mãos todos os privilégios, vocês desagradarão algum religioso obstinado", vocês podem lhe responder: Não, não creio, porque não direi aos meus alunos aquilo que não foi escrito pela mão da natureza do fundo do coração. Eu não creio em nada porque não sirvo a ninguém. Nem esse radical ateu, nem esse religioso reacionário são monstros como vocês nos pintam. Um e outro ama as crianças, e por minha livre vontade canalizará esforços não para subtrair a influência familiar, não para lhes impor opiniões particulares, mas para lhes dar os primeiros princípios de idéias generosas e de bons sentimentos, para Ihes fazer, com a ajuda só das verdades que a intuição permite ele ter, uma alma nobre, pura, direita,amorosa do belo e do bem, capaz de amar Deus, a honra e a pátria.

Somos nós que temos uns aos outros, que acreditamos que isso mesmo não é possível, que não há um terreno comum entre nós, entre as crianças! Professores primários franceses provêm que há apesar de tudo. São vocês que devem tomar o lugar, se vocês quiserem ser os educadores da nossa juventude, e por isso, da nossa sociedade. Aqui, sejam firmes; defendam não o seu direito, mas o direito das gerações jovens; preparemos, prepare para eles um futuro de paz e progresso: aproximar as crianças é como reconciliar os pais, e é isso que a França pede.

Concluo, por onde comecei. O domínio da instrução primária abarca tudo que é intuitivo; vai além em certos pontos, não pode ficar de lado. Permitam reivindicar pela educação do povo, essa palavra do poeta latino que vocês tem repetidamente ouvido: "Eu 
sou homem, e nada do que é humano é estranho para mim". Frequentemente aplico essa máxima no grande ensino universitário; aplico no ensino primário; vocês também devem desenvolver o homem todo inteiro. Não há a disposição de vocês muitos anos e a preciosa disciplina dos estudos clássicos, mas há ao menos, e é suficiente, os instintos que a natureza dá a todo o homem, a luz do bom senso, as forças naturais e espontâneas do coração e da inteligência, enfim essa viva intuição da verdade, do belo e do bem em todas as ordens que são, entre todos nós, as mais inegáveis.

Se a instrução primária souber fazer uso desses recursos naturais e pungentes; se é uma educação e não somente uma aprendizagem; pegando cada uma das nossas faculdades intelectuais e morais, dará resultados melhores, mais direitos e mais fortes; não há entre a instrução popular e a instrução clássica diferença de natureza, mas somente diferença de grau. Uma acaba mais cedo que a outra, mas as duas marcham na mesma via, as duas formam os homens. É por isso que mesmo os humildes estudos primários se ligam à Universidade; é lá que recolhem as velhas e preciosas tradições. Saibam se apropriar, sejam dignos herdeiros, o que Bousset e Fénelon acreditavam ser possível para a educação do príncipe, façam para a educação do povo.

Finalizando, não cabe a mim fechar essa série de reuniões, Mas o Ministro o fará. Mas tenho o dever de agradecer em meu nome e de todos aqueles que palestraram aqui antes de mim. Todos nós estivemos igualmente impressionados e reconhecidos da atenção mantida e da benevolência com a qual vocês nos escutaram. Nós também buscamos entender vocês; talvez mais que vocês, nós desejamos que fosse possível organizar, em vez dessas conferências uma completa e regular troca de idéias entre nós. Mas faltou tempo para chegar a tal organização; os professores primários experimentados como vocês compreendem melhor que outros. Um congresso pedagógico sério não se improvisa, e o Ministro indicou o melhor meio de lhes preparar recomendando as conferências pedagógicas municipais e regionais. Esperamos que no futuro próximo mostre tudo que pode resultar.

Solicito perdão por ter sido extenso e no conjunto incompleto. Desejei, no fundo, recomendar uma coisa bem simples e sobre a qual devemos estar de acordo. Em todo o seu ensino, a toda hora, e até nas horas de desfalecimento, em que não pode sempre se defender, ter fé na natureza humana, fé na criança, nas suas faculdades, no seu bom valor, em todos os seus bons instintos que vocês podem desenvolver; e ainda fé nessa forma particular da natureza humana, que se chama caráter e espírito francês. Respeito pelo passado, reconhecimento pela longa série de ancestrais que abriram o caminho, curiosidade daquilo que se diz e que se faz em torno de nós, sejam, antes de tudo e resolutamente os homens do nosso tempo e do nosso país; e quanto ao futuro, tenho só uma palavra a dizer: Confiança, sim, confiança nos destinos de nossa pátria, porque é a França, e no nosso governo, porque é a República. 